\title{
Meloidogyne incognita parasitizing coffee plants in southern Minas Gerais, Brazil
}

\author{
Marcilene F. A. Santos $^{1}$ (D) - Sônia M. L. Salgado ${ }^{2}$ Joelma G. P. Silva ${ }^{1}$. \\ Valdir R. Correa ${ }^{3}$ - Jório S. F. Mendonça ${ }^{1}$ - Regina M. D. G. Carneiro ${ }^{1}$
}

Received: 21 February 2017 / Accepted: 18 August 2017 / Published online: 18 September 2017

(C) Sociedade Brasileira de Fitopatologia 2017

\begin{abstract}
Root-knot nematodes (RKNs), Meloidogyne spp., represent a serious threat to coffee production in Brazil. Although Meloidogyne exigua is widely spread in southern Minas Gerais, a major region of coffee production, no major yield losses have been reported for this nematode. Due to the risk of introducing other more aggressive nematode species into coffee fields, such as M. incognita and M. paranaensis, a survey for Meloidogyne spp. in coffee fields was carried out in this region. Based on esterase phenotypes and SCAR markers, RKNs were detected in $37.7 \%$ of samples, of which $M$. exigua and M. incognita were present in $31.1 \%$ and $2.2 \%$ of samples, respectively. Mixed populations were observed in $4.4 \%$ of samples, i.e. M. exigua + M. incognita + M. paranaensis, or M. exigua + M. incognita. Meloidogyne exigua was the most prevalent species and occurred in majority of counties. Using SCAR markers, $M$. incognita is reported for the first time in coffee fields located in three counties (Três Pontas, Coqueiral and Aguanil) in southern Minas Gerais. Nematode containment strategies are recommended for this region.
\end{abstract}

Keywords Coffea arabica $\cdot$ Meloidogyne spp. · Detection . Esterase phenotype $\cdot$ SCAR markers

Section Editor: C. Marcelo Oliveira

Marcilene F. A. Santos

lenebio@gmail.com

1 EMBRAPA Recursos Genéticos e Biotecnologia, Brasília, DF 02372, Brazil

2 EPAMIG-Empresa de Pesquisa Agropecuária de Minas Gerais, CP 176, Campus UFLA, Rodovia Lavras-Ijaci, Km 02, Lavras, MG 37200-000, Brazil

3 Instituto Federal de Educação, Ciência e Tecnologia do Tocantins, Campus Dianópolis, Dianópolis, TO 77300-000, Brazil
Root-knot nematodes (RKNs), Meloidogyne spp., occur in several coffee-producing regions in Brazil, being a threat to crop yield. According to Campos and Villain (2005), M. exigua Göldi, 1887 is widely distributed and adapted to several regions, including southern Minas Gerais (MG). This is a major region of coffee production and is at risk of introduction of more aggressive RKN species, such as $M$. paranaensis (Carneiro et al. 1996) and M. incognita (Kofoide and White) Chitwood, which could lead to substantial yield loss (Ferraz 2008).

Recently, $M$. paranaensis and $M$. exigua were detected in Alpinópolis and Coqueiral counties, southern Minas Gerais (Salgado et al. 2015). Meloidogyne incognita is a nematode frequently found parasitizing coffee in São Paulo (SP) state (Carneiro et al. 2005) and has not been detected in Minas Gerais in this crop. Oliveira et al. (2011) reported M. incognita associated with other crops in Minas Gerais state, however, the incompatibility between the MG-population and coffee seedlings was evident at the penetration phase, which was also followed by post-penetration resistance factors impeding nematode establishment. The post-infective development in susceptible coffee seedling occurred only in the M. incognita SP-population.

In order to prevent dissemination of these nematodes into new areas, it is necessary to know the current distribution of these RKN species in this region and promptly adopt measures to contain the disease foci. The objective of this study was to investigate the occurrence and distribution of Meloidogyne spp. in coffee fields located in southern Minas Gerais using PCR SCAR markers and esterase (Est) phenotyping.

Root samples were collected in 45 coffee fields. When possible, females were extracted from roots and characterized with esterase phenotypes (Carneiro et al. 2000; Carneiro and Almeida 2001). The remaining of roots were used for egg extraction using a blender with $0.5 \% \mathrm{NaOCl}$ according to Bonetti and Ferraz (1981). Nematode suspension was placed into a modified Baermann funnel for second-stage juvenile 
(J2) hatching according to Whitehead and Hemming (1965). Juveniles were used to extract DNA using the Quick-gDNA extraction kit (Zymo Research) according to the manufacturer's instructions or according to Randig et al. (2002) and Carneiro et al. (2014). SCAR makers and multiplex PCR reactions were carried out according to Randig et al. (2002).

Coffee cultivar Mundo Novo was grown in $3 \mathrm{~L}$ pots filled with a mixture (1:1) of autoclaved soil and Bioplant compost under greenhouse conditions. Seedlings with six pairs of leaves were inoculated with 10,000 eggs of $M$. incognita (isolate Aguanil) extracted from infected tomato roots (Solanum lycopersicum L. cv. Santa Clara) using $0.5 \% \mathrm{NaOCl}$ according to Bonetti and Ferraz 1981. Plants were maintained under greenhouse conditions at $25-30{ }^{\circ} \mathrm{C}$, with watering and fertilization as needed. Six months after inoculation, the root system was rinsed with tap water and weighed. Eggs were extracted as mentioned
Table 1 Survey for Meloidogyne spp. associated with coffee in Minas Gerais state

\begin{tabular}{|c|c|c|c|c|}
\hline $\begin{array}{l}\text { Sample } \\
\text { number }\end{array}$ & $\begin{array}{l}\text { Number in } \\
\text { the gel }\end{array}$ & County & $\begin{array}{l}\text { Species identified by } \\
\text { SCAR marker }\end{array}$ & $\begin{array}{l}\text { Species identified } \\
\text { by Esterase } \\
\text { phenotypes (Est) }\end{array}$ \\
\hline 6 & - & Três Pontas & Negative & Negative \\
\hline 7 & 1 & Três Pontas & M. exigua & Negative \\
\hline 8 & 2 & Três Pontas & $\begin{array}{l}\text { M. exigua, } M \text {. incognita } \\
\text { and } M . \text { paranaensis }\end{array}$ & M. exigua $(\mathrm{E} 1)$ \\
\hline 9 & 3 & Três Pontas & M. exigua & M. exigua $(\mathrm{E} 1)$ \\
\hline 10 & 4 & Três Pontas & M. exigua & M. exigua (E2) \\
\hline 11 & 5 & Coqueiral & M. exigua & M. exigua $(\mathrm{E} 1)$ \\
\hline 12 & 6 & Coqueiral & M. exigua & M. exigua (E2) \\
\hline 13 & - & Coqueiral & Negative & Negative \\
\hline 14 & 7 & Coqueiral & M. exigua and $M$. incognita & M. exigua $(\mathrm{E} 1)$ \\
\hline 15 & 8 & Coqueiral & Negative & Negative \\
\hline 16 & 9 & Boa Esperança & M. exigua & M. exigua (E2) \\
\hline 21 & 10 & Três Pontas & M. exigua & M. exigua $(\mathrm{E} 2)$ \\
\hline 22 & 11 & Três Pontas & M. exigua & M. exigua (E2) \\
\hline 23 & 12 & Aguanil & Negative & Negative \\
\hline 24 & 13 & Aguanil & M. incognita & Negative \\
\hline 25 & - & Aguanil & Negative & Negative \\
\hline 26 & 14 & Aguanil & M. exigua & M. exigua (E2) \\
\hline 27 & - & Boa Esperança & M. exigua & Negative \\
\hline 28 & - & Boa Esperança & Negative & Negative \\
\hline 29 & - & Boa Esperança & Negative & Negative \\
\hline 30 & - & Boa Esperança & M. exigua & Negative \\
\hline 31 & - & Boa Esperança & Negative & Negative \\
\hline 32 & - & Boa Esperança & Negative & Negative \\
\hline 33 & - & Boa Esperança & Negative & Negative \\
\hline 34 & - & São José da Barra & Negative & Negative \\
\hline 35 & - & São José da Barra & Negative & Negative \\
\hline 36 & - & São José da Barra & Negative & Negative \\
\hline 37 & - & Santo Antônio do Amparo & M. exigua & Negative \\
\hline 38 & - & Santo Antônio do Amparo & M. exigua & Negative \\
\hline 39 & - & Santo Antônio do Amparo & Negative & Negative \\
\hline 40 & - & Santo Antônio do Amparo & M. exigua & Negative \\
\hline 41 & - & Santo Antônio do Amparo & Negative & Negative \\
\hline 42 & - & Camacho & Negative & Negative \\
\hline 43 & - & Camacho & Negative & Negative \\
\hline 44 & - & Camacho & Negative & Negative \\
\hline 45 & - & Camacho & Negative & Negative \\
\hline
\end{tabular}

(-) samples not included in Fig. 1 


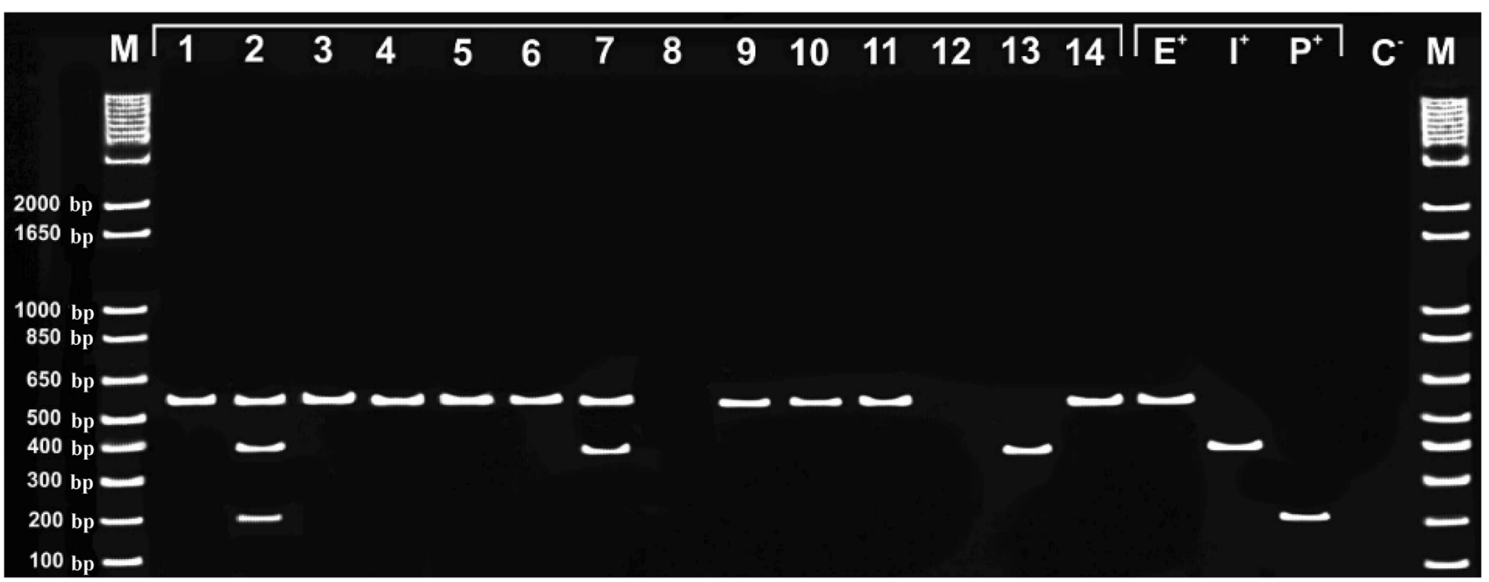

Fig. 1 Nematode identification in samples from different locations in Minas Gerais state using SCAR-PCR. Sample numbers: 1-4 and 10-11, Três Pontas; 5-8, Coqueiral; 9, Boa Esperança; 12, Aguanil. Abbreviations: $E^{+}$,

above using $1 \% \mathrm{NaOCl}$ and quantified under a light microscope using Peters' slides. The reproduction factor $(\mathrm{RF})$ was calculated as $\mathrm{RF}=\mathrm{FP} / \mathrm{IP}$, where $\mathrm{FP}=$ final nematode population and $\mathrm{IP}=$ initial nematode population $(\mathrm{IP}=10,000)$.

Nematodes in most of the samples were identified either by SCAR markers or by Est profile. RKNs were detected in $37.7 \%$ of samples, including M. exigua (Est E1, E2, 562 bp fragment) in $80 \%$ of positive samples and M. incognita (399 bp fragment) in $5 \%$ of positive samples. RKNs were also detected in mixtures in $10 \%$ of positive samples, including M. exigua + M. incognita + M. paranaensis (208 bp fragment) and M. exigua + M. incognita (Table 1, Fig. 1). Most of the populations were identified as M. exigua with SCAR markers, which was more efficient in its detection compared to Est phenotyping (Table 1, Fig. 1), since M. exigua is more difficult to be detected using the isoenzyme phenotype due to the low concentration of esterase in this coffee RKN species (Carneiro et al. 2000). The species M. incognita and $M$. paranaensis were not detected in coffee roots through esterase phenotypes due to their low occurrence and bad condition of samples (Table 1), a fact frequently found in coffee roots. Meloidogyne exigua was detected in almost every sampled
Meloidogyne exigua; $\mathrm{I}^{+}$, M. incognita, $\mathrm{P}^{+} ;$M. paranaensis; C-, Negative control, $\mathrm{M}$, molecular weight marker

county, except in Camacho, where no nematodes were detected. This survey confirmed M. exigua as a major RKN species associated with coffee damage in coffee-producing areas in Minas Gerais (Gonçalves and Silvarolla 2001; Carneiro et al. 2005; Ferraz 2008; Salgado et al. 2015).

The SCAR multiplex-PCR method allowed amplification of specific DNA fragments from only a few $\mathrm{J} 2$ extracted from roots or soil (Randig et al. 2002, 2004). This species-specific marker allowed detection of M. exigua, M. incognita and M. paranaensis in mixtures from field samples, confirming the results obtained by Carneiro et al. (2005). This result was not possible to obtain using Est phenotyping, showing that this marker is less effective with samples containing mix of species in small numbers and females in bad condition for analyses, which results from the advanced degree of root decomposition occurring when roots are parasitized by M. paranaensis and M. incognita (Fig. 2).

Meloidogyne exigua was widely distributed in southern Minas Gerais, while M. incognita occurred only in three counties (Aguanil, Coqueiral, Três Pontas). Meloidogyne paranaensis was detected only in one sample (Três Pontas) (Table 1, Fig. 1). This species was previously detected in Minas Gerais
Fig. 2 Esterase (Est) phenotypes of Meloidogyne exigua populations found in fields of some coffee-producing areas in southern Minas Gerais. J3, M. javanica (Est reference); a) Sample numbers: 2, 3, 5 and 7 (Est E1- M. exigua, one band); b) 4, 6, 9, 10, 11 and 14 (Est E2 M. exigua, two bands)

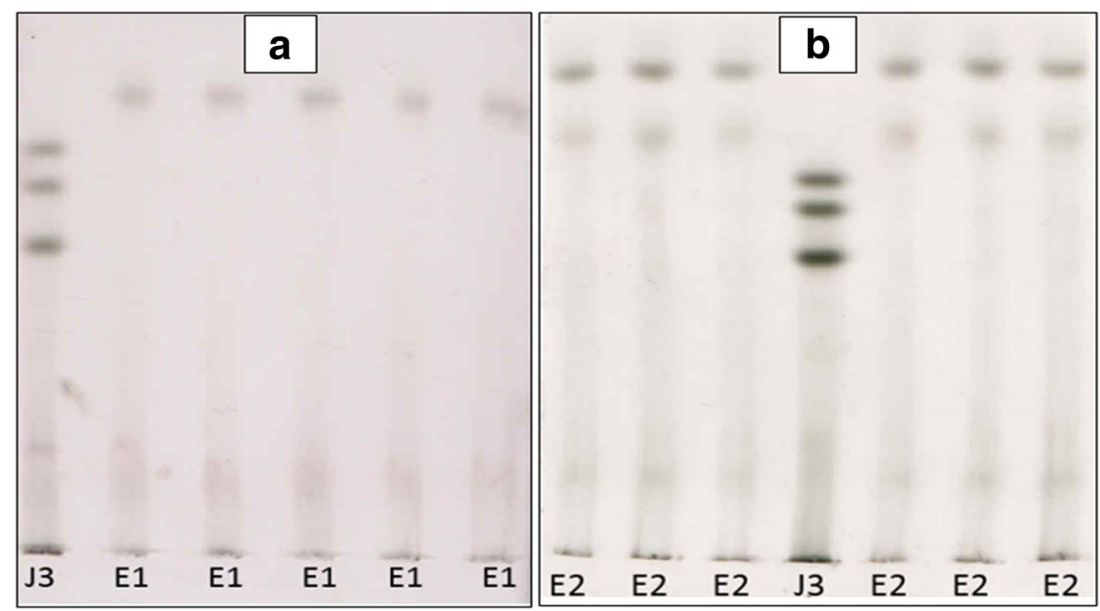


in the counties of Serra do Salitre and Patrocínio (in Alto Paranaíba region) (Castro et al. 2003), Piumhi (Castro et al. 2008), Alpinópolis and Coqueiral (Salgado et al. 2015).

In greenhouse tests, arabica coffee plants cv. Mundo Novo inoculated with the original $M$. incognita population from Aguanil (maintained in tomato plants cv. Santa Clara for nine months with three successive inoculations) showed typical symptoms of swellings evolving into extensive areas of corky tissues and reduced fresh weight of roots. Symptoms of swelling and cracking were similar to those observed in the field. This population reproduced well in coffee plants as shown by the nematode RF (32.2). These results confirmed the pathogenicity of the M. incognita population from Aguanil (MG) on susceptible coffee plants (Koch's postulates), differing from results obtained by Oliveira et al. 2011, who reported that the M. incognita MG-population was unable to infect susceptible coffee plants (Oliveira et al. 2011). The genetic variability of $M$. incognita isolates was studied by Santos et al. 2012. Overall, they showed a low genetic variability in this species. In addition, no association was observed between the genetic variability of four $M$. incognita races studied and clustering in phylogenetic analyzes (Santos et al. 2012). These findings suggest that $M$. incognita races and pathotypes are not determined by overall genetic differences (Carneiro and Cofcewicz 2008). Thus, the physiological variability of $M$. incognita isolates needs to be further studied.

The actual distribution of M. incognita in Minas Gerais state is not known because of the small number of samples collected in this preliminary study. This study showed only a restricted occurrence of this species on coffee plants and its ability to parasitize the susceptible coffee cultivar Mundo Novo.

This is the first report of $M$. incognita parasitizing coffee plants in three counties of southern Minas Gerais. This finding has great importance for the agriculture in Minas Gerais, considering this nematode may damage coffee plants and become an additional problem for this crop. Although the occurrence of M. incognita and M. paranaensis is still restricted in southern Minas Gerais, these results show the importance to adopt measures for their containment in this region, where coffee production is socioeconomically important for the state.

Acknowledgements The authors thank Consórcio Pesquisa Café, Fundação de Amparo a Pesquisa do Estado de Minas Gerais (FAPEMIG), INCT CAFÉ and Conselho Nacional de Pesquisa (CNPq) for their financial support and scholarships.

\section{References}

Bonetti JI, Ferraz S (1981) Modificações no método de Hussey \& Barker para extração de ovos de Meloidogyne exigua em raízes de cafeeiro. Fitopatologia Brasileira 6:533
Campos VP, Villain L (2005) Nematode parasites of coffee, cocoa and tea. In: Luc M, Sikora RA, Bridge J (eds) Plant parasitic nematodes in subtropical and tropical agriculture. CAB International, Wallingford, pp 529-579

Carneiro RMDG, Almeida MRA (2001) Técnica de eletroforese usada no estudo de enzimas dos nematoides de galhas para identificação de espécies. Nematologia Brasileira 25:35-44

Carneiro RMDG, Cofcewicz (2008) Taxonomy of coffee-parasitic rootknot nematodes, Meloidogyne spp. In: Souza RM (ed) Plant parasitic nematodes of coffee. Springer, New York, pp 87-122

Carneiro RMDG, Carneiro RG, Abrantes MO, Santos MFA, Almeida MR (1996) Meloidogyne paranaensis n. sp. (Nemata: Meloidogynidae), a root-knot nematode parasitizing coffee in Brazil. Journal of Nematology 28:177-189

Carneiro RMDG, Almeida MRA, Quénéhervé P (2000) Enzyme phenotypes of Meloidogyne spp. populations. Nematology 2:645-654

Carneiro RMDG, Randig O, Almeida MRA, Gonçalves W (2005) Identificação e caracterização de espécies de Meloidogyne em cafeeiros nos estados de São Paulo e Minas Gerais através dos fenótipos de esterase e SCAR- Multiplex- PCR. Nematologia Brasileira 29:233-241

Carneiro RMDG, Correa VR, Castagnone-Sereno P (2014) Practical aspects of biochemical and molecular diagnosis applied to Meloidogyne species. Sanidade de raízes/NETFIT - Núcleo de Estudos em Fitopatologia. 1ed. Suprema Gráfica e Editora, São Paulo. pp. 79-98

Castro JMC, Naves RL, Campos VP (2003) Ocorrência de Meloidogyne paranaensis em cafeeiro na região do Alto Paranaíba em Minas Gerais. Fitopatologia Brasileira 28:565

Castro JMC, Campos VP, Pozza EA, Naves RLC, Andrade Júnior WC, Dutra MR, Coimbra JL, Maximiniano C, Silva JRC (2008) Levantamento de fitonematóides em cafezais do Sul de Minas Gerais. Nematologia Brasileira 32:56-64

Ferraz LCBF (2008) World reports: Brazil. In: Souza RM (ed) Plant parasitic nematodes of coffee. APS Press \& Springer, New York, pp 225-248

Gonçalves W, Silvarolla MB (2001) Nematoides parasitas do cafeeiro. In: Zambolim L (ed) Tecnologias de produção de café com qualidade. Editora UFV, Viçosa, pp 199-267

Oliveira DS, RD'AL O, Silva DG, Silva RV (2011) Characterization of Meloidogyne incognita populations from São Paulo and Minas Gerais state and their pathogenicity on coffee plants. Tropical Plant Pathology 36:190-194

Randig O, Bongiovanni M, Carneiro RMDG, Castagnone-Sereno P (2002) Genetic diversity of root-knot nematodes from Brazil and development of SCAR markers specific for the coffee-damaging species. Genome 45:862-870

Randig O, Carneiro RMDG, Castagnone-Sereno P (2004) Identificação das principais espécies de Meloidogyne parasitas do cafeeiro no Brasil com marcadores SCAR-CAFÉ em Multiplex-PCR. Nematologia Brasileira 28:1-10

Salgado SML, Guimarães NMRB, Botelho CE, Tassome GAT, Marcelo AL, Souza SR, Oliveira RDL, Ferreira DF (2015) Meloidogyne paranaensis e Meloidogyne exigua em lavouras cafeeiras na região sul de Minas Gerais. Coffee Science 10:475-481

Santos MFA, Furlanetto C, Almeida MRA, Carneiro MDG, Mota FC, Gomes ACMM, Silveira NOR, Silva JGP, Castagnone-Sereno P, Tigano MS, Carneiro RMDG (2012) Biometrical, biological, biochemical and molecular characteristics of Meloidogyne incognita isolates and related species. European Journal of Plant Pathology 134:671-684

Whitehead AG, Hemming JR (1965) A comparison of some quantitative methods of extracting small vermiform nematodes from soil. Annals in Applied Biology 55:25-38 